\title{
Exposure to dust and rat urinary aeroallergens in research establishments
}

M J Nieuwenhuijsen, S Gordon, R D Tee, K M Venables, J C McDonald, A J Newman Taylor

\begin{abstract}
As part of an epidemiological study rat urinary aeroallergen (RUA) and total dust concentrations were measured at three research establishments. Personal RUA measurements in nine exposure groups over a workshift showed highest exposure for animal technicians (geometric mean $\left.(G M)=32.4 \mu \mathrm{g} / \mathrm{m}^{3}\right)$ and lowest for workers in slide production and office (GM $\left.\geqslant 0.1 \mu \mathrm{g} / \mathrm{m}^{3}\right)$. Except for slide production workers, contact with rats, their tissues, faeces, or urine comprised less than half the work shift. Exposure during contact with rats was considerably higher. Personal RUA measurements in nine task categories showed high RUA concentrations for handling rats $\left(G M=68 \cdot 0 \mu \mathrm{g} / \mathrm{m}^{3}\right)$ and cleaning out $\left(G M=53.6 \mu \mathrm{g} / \mathrm{m}^{3}\right)$. Traces of RUA could still be measured in tearooms inside and near offices outside the animal houses. Total dust concentrations were low.
\end{abstract}

(Occup Environ Med 1994;51:593-596)

Department of Occupational and Environmental Medicine, National Heart and Lung Institute, Royal Brompton and National Heart Hospital, London M J Nieuwenhuijsen $S$ Gordon RD Tee $\mathrm{K} M$ Venables J C McDonald A J Newman Taylor Correspondence to: Mark J Nieuwenhuijsen, Department of Occupational and Environmental Medicine, National Heart and Lung Institute, $1 B$ Manresa Road, London SW3 6LR

Accepted 16 May 1994
Keywords: allergen, rat urinary aeroallergen, total dust, exposure assessment

As part of an epidemiological study to explore the relation between occupational exposure to laboratory animals and laboratory animal allergy we measured the dust and rat urinary aeroallergen (RUA) concentrations in three research institutes. This paper describes the RUA exposure assessment used to provide exposure estimates for a longitudinal prospective epidemiological study, of which the first results have been published in a companion paper. ${ }^{1}$ Measurements were made over a whole workshift and during the performances of identified tasks to obtain a comprehensive picture of RUA exposure for subjects in the study.
Table 1 Task categories in laboratory animal workers

\footnotetext{
No or minimal exposure: work without animal contact.

Slide production: making slides of frozen tissue.

Postmortem: necropsy of animals.

Experiments: experimental work on anaesthetised animals.

Handling animals: handling of animals in animal rooms - for example, shaving, weighing, and dosing.

Indirect contact: work in animal rooms without handling animals-for example, writing labels and changing and filling bottles.

Cleaning out: cleaning out cages and floor sweeping in animal rooms.

Cage wash: bottle and cage wash in cage wash area.

Corridor work: work in corridor inside animal house.
}

Laboratory animal allergy is often reported in animal technicians and researchers exposed to rats, mice, and other small mammals, and is among the highest occupational risks of asthma in Britain today. ${ }^{2}$ Cross sectional epidemiological studies have shown that up to a third of those exposed to these animals reported allergic symptoms. ${ }^{3-5}$ The animals' urine has been identified as a major source of allergens, ${ }^{6}$ and recently developed immunoassays have made it possible to measure them in the air. ${ }^{78}$

In previous studies the highest exposure to RUA over a work shift was measured in animal technicians and much lower exposure in researchers and supervisors. ${ }^{910}$ Tasks associated with the highest RUA exposure were cleaning, feeding, handling, and injection of the animals. ${ }^{8911}$ Other important determinants for the RUA concentration were the number of animals involved, stock density, ventilation, and humidity. ${ }^{81112}$

\section{Material and methods} SITES AND EXPOSURE GROUPS

Departments of three research institutes (sites $A$ and B), where there was work with rats, were selected. Two institutes based next to each other were treated as one site (site B). An occupational hygienist (MJN) visited each site and divided the employees into nine exposure groups guided by the zoning strategy described by Corn and Esmen. ${ }^{13}$ The nine exposure groups were: scientists and laboratory technicians, cage cleaners, supervisors, animal technicians, workers in the office, in slide production, in maintenance, and in postmortem examinations, and a miscellaneous group. A sample of employees in each exposure group, aimed at including sufficient numbers to include at least one out of the $10 \%$ highest exposed workers, were asked to wear a personal sampler for a whole workshift and to keep a record detailing times spent in the rooms, tasks performed, and species worked with. Unfortunately insufficient numbers were obtained for scientists, office and maintenance workers, and supervisors.

\section{TASK CATEGORIES}

During a workshift various tasks were performed. These were grouped into nine task categories (table 1). During one week all employees in one animal house were asked to wear a personal sampler while performing any of the identified tasks. The filters and samplers were changed every time a new task was 
Plot of rat urinary aeroallergen against total dust measurements.

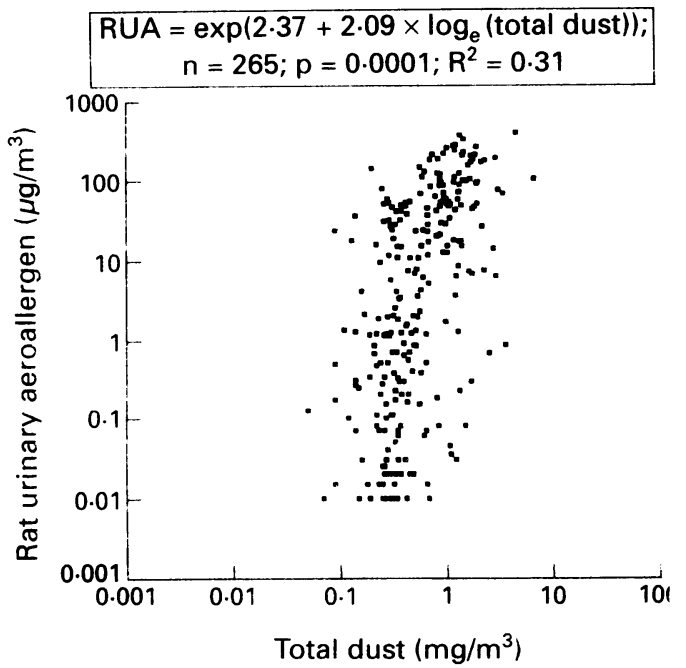

performed. As well as personal sampling, static samples were collected in various parts of the research institutes to measure background concentrations of RUA.

AIR SAMPLING

For all measurements, the samplers (Casella AFC123, Casella London, Bedford) were connected to seven hole sampling heads (Casella London, Bedford) each containing preweighed polytetrafluoroethylene filters $(1 \cdot 2$ $\mu \mathrm{m}$ pore size, $25 \mathrm{~mm}$ diameter; Sartorius Instruments, GB-Belmont, Surrey) and were run at a flow rate of $2 \mathrm{l} / \mathrm{min}$. The filters were weighed on a six figure balance (Sartorius R180D, Sartorius Instruments, GB-Belmont, Surrey) before and after sampling and returned to the laboratory for elution and RUA measurement. The total coefficient of variation, obtained by stationary sampling, for dust was $15 \cdot 8 \%$ with a detection limit of $0 \cdot 12$ $\mathrm{mg} / \mathrm{m}^{3}$. For total dust a value of half the detection limit was assigned to samples under the detection limit.

ELUTION

Filters were eluted in $2 \mathrm{ml} 0 \cdot 1 \mathrm{M} \mathrm{NH}_{4} \mathrm{HCO}_{3}$ with $0.5 \% \mathrm{v} / \mathrm{v}$ Tween 20 for two hours in Sterilin RT-30 tubes $(7 \cdot 4 \times 1 \cdot 1 \mathrm{~cm})$ (A1 Laboratory supplies, London) by vortexing at two one-hour intervals. ${ }^{14}$ Filters were freeze dried and reconstituted before assay.
ASSAY

Urine was collected daily from adult male Sprague-Dawley rats in metabolic cages (Techniplast) and processed as decribed by Gordon et al. ${ }^{8}$ The RUA content of the filters was measured by radioallergosorbent inhibition, with pooled serum samples from eight patients allergic to rat urine, as described by Gordon et al. ${ }^{8}$ The standard curve $(200 \mu \mathrm{g} / \mathrm{ml}$ to $0.025 \mu \mathrm{g} / \mathrm{ml}$ rat urine in twofold dilutions) was constructed with a four parameter logistic curve fit. The amount of RUA of air samples was automatically interpolated (Cobra autogamma counter 5005, Canberra-Packard, Pangbourne, Berks). The RUA concentration was calculated by correction for volume of air sampled and reconstituted volume. A detailed description and evaluation of the RUA assay has been reported elsewhere. ${ }^{15}$ The total coefficient of variation, obtained by stationary sampling, for the RUA sampling was $47.5 \%$ with a detection limit of $50 \mathrm{ng} / \mathrm{ml}$. Half the value of the detection limit was assigned to samples when RUA was not detectable.

\section{STATISTICAL ANALYSIS}

The statistical software package SAS (SAS Institute, Cary NC, USA) was used for descriptive statistical analysis. Regression analysis was used to assess the relation between total dust and RUA.

\section{Results}

EXPOSURE GROUPS

Of 278 personal shift samples collected, 13 were discarded due to filter irregularities or sampler breakdown leaving 265 for analyses. The total dust and RUA concentrations were significantly correlated $(r=0.56, \quad \mathrm{P}=$ $0 \cdot 0001)$, but whereas there was little variation in total dust (range $0.05-6.81 \mathrm{mg} / \mathrm{m}^{3}$ ) variation in RUA concentrations was large (range $0.01-399.11 \mu \mathrm{g} / \mathrm{m}^{3}$ ) (fig 1, table 2). Average total dust concentrations were low (table 2).

The highest personal concentrations of RUA over a shift were measured in animal technicians and cage cleaners at site $B$, the lowest in office and slide production workers (table 2). The variation within the exposure groups, expressed as the geometric SD (GSD)

Table 2 Rat urinary aeroallergen and total dust concentrations by exposure group and site

\begin{tabular}{|c|c|c|c|c|c|c|c|c|c|c|c|c|}
\hline & \multicolumn{7}{|c|}{ Rat urinary aeroallergen $\left(\mu \mathrm{g} / \mathrm{m}^{3}\right)$} & \multicolumn{5}{|c|}{ Total dust $\left(\mathrm{mg} / \mathrm{m}^{3}\right)$} \\
\hline & No & $N d$ & $A M$ & $G M$ & $G S D$ & Min & $\operatorname{Max}$ & $A M$ & $G M$ & $G S D$ & Min & $\operatorname{Max}$ \\
\hline $\begin{array}{l}\text { Site A: } \\
\text { Slide production }\end{array}$ & 30 & 13 & $0 \cdot 1$ & $0 \cdot 0$ & $3 \cdot 0$ & 0.01 & $1 \cdot 17$ & $0 \cdot 28$ & $0 \cdot 27$ & 1.5 & $0 \cdot 14$ & 0.49 \\
\hline Office & 2 & 0 & $0 \cdot 2$ & $0 \cdot 1$ & - & 0.05 & 0.27 & $0 \cdot 25$ & 0.25 & 10 & 0.25 & 0.25 \\
\hline Scientist & 30 & 12 & $3 \cdot 4$ & $0 \cdot 1$ & $8 \cdot 2$ & 0.01 & $95 \cdot 33$ & $0 \cdot 38$ & 0.33 & 1.7 & 0.06 & $1 \cdot 20$ \\
\hline Supervisor & 10 & 0 & $1 \cdot 1$ & 0.5 & 4.5 & 0.02 & $5 \cdot 59$ & 0.63 & $0 \cdot 32$ & $2 \cdot 9$ & 0.06 & 3.68 \\
\hline Cage cleaner & 10 & 1 & $2 \cdot 8$ & $1 \cdot 2$ & $6 \cdot 3$ & 0.01 & $14 \cdot 87$ & $0 \cdot 34$ & $0 \cdot 31$ & 1.5 & $0 \cdot 14$ & 0.69 \\
\hline Postmortem & 21 & 0 & $2 \cdot 9$ & $1 \cdot \overline{6}$ & $3 \cdot 2$ & $0 \cdot 11$ & $15 \cdot 06$ & $0 \cdot 40$ & $0 \cdot 36$ & $1 \cdot 7$ & 0.06 & 3.68 \\
\hline Miscellaneous & 5 & 0 & $4 \cdot 4$ & $3 \cdot 6$ & $2 \cdot 2$ & $1 \cdot 20$ & $6 \cdot 78$ & 0.94 & 0.62 & $2 \cdot 5$ & $0 \cdot 30$ & $2 \cdot 98$ \\
\hline $\begin{array}{l}\text { Animal technician } \\
\text { Site B: }\end{array}$ & 93 & 0 & $81 \cdot 5$ & $30 \cdot 2$ & $8 \cdot 0$ & 0.07 & $375 \cdot 35$ & $1 \cdot 11$ & 0.83 & $2 \cdot 2$ & 0.06 & $6 \cdot 81$ \\
\hline Maintenance & 1 & 0 & 0.3 & - & - & - & - & 1.74 & 1.74 & - & - & - \\
\hline Scientist & 30 & 2 & $4 \cdot 3$ & $1 \cdot 6$ & $5 \cdot 6$ & 0.07 & $142 \cdot 26$ & 0.51 & $0 \cdot 34$ & $2 \cdot 6$ & 0.06 & $2 \cdot 00$ \\
\hline Cage cleaner & 7 & 0 & $35 \cdot 2$ & $26 \cdot 2$ & $2 \cdot 4$ & $7 \cdot 35$ & $71 \cdot 86$ & 1.06 & $0 \cdot 83$ & $2 \cdot 1$ & $0 \cdot 13$ & $4 \cdot 63$ \\
\hline Animal technician ${ }^{\star}$ & 32 & 5 & $78 \cdot 1$ & $32 \cdot 4$ & $5 \cdot 0$ & 0.82 & $399 \cdot 11$ & $1 \cdot 30$ & $1 \cdot 16$ & $1 \cdot 7$ & 0.46 & $2 \cdot 30$ \\
\hline
\end{tabular}

$\star=$ without those who work with isolators; No = number of samples; $\mathrm{Nd}=$ number of samples under the detection limit $\mathrm{AM}=$ arithmetic mean; $\mathrm{GM}=$ geometric mean; $\mathrm{GSD}=$ geometric $\mathrm{SD} ;$ Min = minimum value measured; Max = maximum value measured. 
Table 3 Proportion (\%) of an $8 \mathrm{~h}$ shift spent on tasks with contact with rats, their tissues, faeces, or urine

\begin{tabular}{|c|c|c|c|c|c|c|c|c|}
\hline & $\begin{array}{l}\text { Proportion of } \\
\text { total shift }\end{array}$ & $\begin{array}{l}\text { Slide } \\
\text { production }\end{array}$ & Postmortem & Experiments & Handling & $\begin{array}{l}\text { Indirect } \\
\text { contact }\end{array}$ & $\begin{array}{l}\text { Cleaning } \\
\text { out }\end{array}$ & $\begin{array}{l}\text { Cage } \\
\text { wash }\end{array}$ \\
\hline \multicolumn{9}{|l|}{ Site A: } \\
\hline Office & $0 \cdot 0$ & 0.0 & $0 \cdot 0$ & $0 \cdot 0$ & 0.0 & 0.0 & $0 \cdot 0$ & 0.0 \\
\hline Animal technician & $29 \cdot 3$ & 0.0 & 0.5 & 0.0 & $14 \cdot 2$ & $9 \cdot 3$ & $5 \cdot 2$ & 0.0 \\
\hline Scientist & 1.0 & 0.0 & $3 \cdot 1$ & 0.5 & $0 . \overline{4}$ & $0 \cdot 1$ & $0 . \overline{0}$ & 0.0 \\
\hline Cage cleaner & $31 \cdot 4$ & 0.0 & 0.0 & 0.0 & $1 \cdot 6$ & $1 \cdot 4$ & $0 \cdot 0$ & $27 \cdot 3$ \\
\hline Supervisor & $5 \cdot 2$ & 0.0 & 0.0 & 0.0 & $5 \cdot 1$ & $0 \cdot 1$ & $0 \cdot 0$ & 0.0 \\
\hline Postmortem & $46 \cdot 8$ & 0.0 & $46 \cdot 8$ & 0.0 & 0.0 & 0.0 & 0.0 & 0.0 \\
\hline Slide production & $65 \cdot 0$ & $65 \cdot 0$ & 0.0 & $0 \cdot 0$ & $0 \cdot 0$ & 0.0 & 0.0 & 0.0 \\
\hline $\begin{array}{l}\text { Miscellaneous } \\
\text { Site B: }\end{array}$ & $0 \cdot 0$ & 0.0 & $0 \cdot 0$ & 0.0 & 0.0 & 0.0 & $0 \cdot 0$ & 0.0 \\
\hline Animal technician & $17 \cdot 8$ & 0.0 & 0.0 & 0.0 & $3 \cdot 1$ & $9 \cdot 9$ & $4 \cdot 7$ & $0 \cdot 0$ \\
\hline Scientist & $20 \cdot 7$ & 0.0 & 0.7 & $9 \cdot 9$ & $9 \cdot 6$ & 0.4 & $0 \cdot 0$ & 0.0 \\
\hline Cage cleaners & $45 \cdot 2$ & 0.0 & $0 \cdot 0$ & 0.0 & 0.0 & 0.0 & 0.0 & $45 \cdot 2$ \\
\hline Maintenance & $9 \cdot 4$ & 0.0 & 0.0 & 0.0 & 0.0 & $9 \cdot 4$ & 0.0 & 0.0 \\
\hline
\end{tabular}

was very large, which might be due to differences in time working with rats. The time spent working with rats for each task and in total was calculated from the work record sheets. This showed that, except for slide production workers, employees spent less than half their time working with rats, their tissues, urine, or faeces (table 3).

The RUA personal sampling results were recalculated with the time employees worked with rats instead of total sampling time. Time working with frozen tissues used in slide production and animals in isolators was not included. Office workers and workers in the miscellaneous group did not report any work with rats. Table 4 shows that animal technicians in particular experienced a much higher exposure to RUA while working with rats, and that variation in RUA concentrations within exposure groups decreased although it is still large. Five of the six samples from animal technicians working with rats in isolators contained no detectable amount of RUA and the sixth had a concentration of $0.22 \mu \mathrm{g} / \mathrm{m}^{3}$.

\section{TASK CATEGORIES}

One hundred and ninety task samples were collected and analysed (table 5); 52 shift samples where work entailed only one task working with rats are also shown. The sampling time for handling rats, indirect contact, and cage cleaning ranged from nine to 160 minutes (mean 37 minutes) and for postmortem examination from 167 to 393 minutes (mean of 303 minutes). Tasks entailing exposure to a large number of conscious rats (handling and cleaning out) were associated with the highest exposure to RUA. Indirect contact was associated with lower exposures. Exposure to RUA for tasks such as experimental work and cage washing was significantly lower but still detectable.

\section{STATIC SAMPLES}

Whole shift static samples showed measurable concentrations of RUA in 20 of 25 samples in corridors (geometric mean $(\mathrm{GM})=0 \cdot 1$ ), in four of six samples in tea rooms inside site $A$ animal houses (GM $=0 \cdot 2$ ), and in three of six samples near offices outside the animal houses of site $B(G M=0 \cdot 1)$. The highest static concentrations were measured within the animal rooms $(\mathrm{GM}=3 \cdot 8, \mathrm{n}=18)$.

\section{Discussion}

These findings present the relation between total dust and RUA. They give a comprehensive picture of the average RUA exposure that employees might be expected to experience over a day as well as and while performing certain tasks; they also describe the time spent on various tasks working with rats.

There was a significant relation between the total dust and RUA measurements, but the dust showed little variation in contrast to the wide range in RUA. The average total dust concentrations were low. Concentrations of RUA seem to show a higher discrimination between exposure groups and might therefore be preferred above total dust concentrations for use in epidemiological studies.

As shown previously, ${ }^{10}$ animal technicians experienced the highest exposure to RUA, many times more than in any other exposure group, especially after taking into account the time working with rats. The main difference in exposure between groups at the two sites was found among cage cleaners and was prob-

Table 4 Rat urinary aeroallergen concentrations $\left(\mu \mathrm{g} / \mathrm{m}^{3}\right)$ by exposure group and site (for time working with rats)

\begin{tabular}{|c|c|c|c|c|c|c|c|c|c|c|c|c|c|c|}
\hline & \multicolumn{7}{|c|}{ Site $A$} & \multicolumn{7}{|c|}{ Site $B$} \\
\hline & No & $N d$ & $A M$ & $G M$ & $G S D$ & Min & $\operatorname{Max}$ & No & $N d$ & $A M$ & $G M$ & $G S D$ & $\operatorname{Min}$ & $\operatorname{Max}$ \\
\hline $\begin{array}{l}\text { Slide production } \\
\text { Office } \\
\text { Miscellaneous }\end{array}$ & & & & $\begin{array}{l}\text { NRC } \\
\text { NRC } \\
\text { NRC }\end{array}$ & & & & & & & & & & \\
\hline $\begin{array}{l}\text { Maintenance } \\
\text { Postmortem }\end{array}$ & 20 & 0 & $3 \cdot 7$ & $2 \cdot 2$ & 2.8 & & & 1 & 0 & $1 \cdot 4$ & $1 \cdot 4$ & - & - & - \\
\hline Cage cleaner & 9 & 1 & $10 \cdot 6$ & $\begin{array}{l}2 \cdot 2 \\
4 \cdot 2\end{array}$ & $11 \cdot 2$ & 0.01 & $22 \cdot 44$ & 7 & 0 & $35 \cdot 3$ & $26 \cdot 3$ & $2 \cdot 4$ & $7 \cdot 35$ & $71 \cdot 86$ \\
\hline Supervisor & 2 & 0 & $21 \cdot 6$ & $6 \cdot 3$ & - & 0.95 & $42 \cdot 25$ & & & & & & & \\
\hline Scientist & 2 & 0 & $254 \cdot 3$ & $17 \cdot 7$ & - & 0.62 & $507 \cdot 95$ & 26 & 0 & $27 \cdot 0$ & $8 \cdot 0$ & $8 \cdot 4$ & 0.08 & $142 \cdot 26$ \\
\hline Animal technician & 83 & 0 & $203 \cdot 7$ & $118 \cdot 6$ & $4 \cdot 0$ & $0 \cdot 85$ & $1280 \cdot 83$ & 23 & 0 & $191 \cdot 4$ & $101 \cdot 2$ & $4 \cdot 0$ & $2 \cdot 21$ & $540 \cdot 05$ \\
\hline
\end{tabular}

NRC = no rat contact recorded; other abbreviations as for table 2 . 
Table 5 Rat urinary aeroallergen concentrations $\left(\mu \mathrm{g} / \mathrm{m}^{3}\right)$ of the task categories

\begin{tabular}{|c|c|c|c|c|c|c|c|}
\hline & No & $N d$ & $A M$ & $G M$ & $G S D$ & CIL & $C I H$ \\
\hline Corridor work & 2 & 2 & ND & _. & - & -- & - \\
\hline Non/minimal contact ${ }^{\star}$ & 12 & 9 & $0 \cdot 1$ & $0 \cdot 0$ & $2 \cdot 6$ & $0 \cdot 0$ & $0 \cdot 1$ \\
\hline Slide production $\star$ & 30 & 13 & $0 \cdot 1$ & $0 \cdot 0$ & $3 \cdot 0$ & $0 \cdot 0$ & $0 \cdot 1$ \\
\hline Experiments ${ }^{\star}$ & 6 & 0 & $0 \cdot 4$ & $0 \cdot 2$ & $2 \cdot 7$ & $0 \cdot 1$ & $0 \cdot 7$ \\
\hline Postmortem & 26 & 1 & $0 \cdot 4$ & $0 \cdot 3$ & $2 \cdot 1$ & $0 \cdot 3$ & 0.5 \\
\hline Cage wash ${ }^{\star}$ & 4 & 0 & 4.5 & 0.9 & $15 \cdot 9$ & $0 \cdot 0$ & $73 \cdot 6$ \\
\hline Indirect contact & 57 & 2 & $45 \cdot 5$ & $21 \cdot 3$ & $4 \cdot 1$ & $14 \cdot 6$ & $31 \cdot 0$ \\
\hline Cleaning out & 48 & 0 & $121 \cdot 6$ & $53 \cdot 6$ & $4 \cdot 3$ & $35 \cdot 1$ & $82 \cdot 0$ \\
\hline Handling rats & 57 & 0 & $127 \cdot 0$ & $68 \cdot 0$ & $3 \cdot 7$ & $48 \cdot 1$ & $96 \cdot 1$ \\
\hline
\end{tabular}

ॠTaken from shift measurements; CIL = lower $95 \%$ confidence limit around GM; CIH = upper $95 \%$ confidence limit around GM; ND = not detectable; other abbreviations as for table 2 .

ably related to different work practices. The cleaners at site $B$ were required to scrape out sawdust before washing the cages; at site A they generally only washed the cages. Animal technicians spent a large part of their shift without rat contact, mainly because the various species were kept in separate rooms and paperwork was done elsewhere. Scientists, laboratory technicians, and supervisors recorded short contact with rats due to the nature of their work.

As other studies have found, ${ }^{8911}$ tasks associated with high RUA exposure were cleaning out cages and handling rats, with lower exposure for tasks in the animal rooms without major disturbance of rats. Work with a small number or unconscious rats, their faeces, or urine was associated with much lower RUA concentrations.

The large variation within groups and task categories underlines the complexity of exposure assessment for laboratory animal workers and is partly due to the numerous exposure determinants. Workers create their own working environment by spending variable times performing different tasks in various small rooms with varying numbers of animals of different sex, age, and type, and varying levels of ventilation at different times.

Measurable amounts of RUA were detected outside the animal houses near the office area of the sites. This shows possible RUA exposure for employees not working with animals directly. Traces of RUA, proba- bly transported there on clothing, were also found in tea rooms inside the animal houses.

We acknowledge the help of Miss J Welch with air filter elution, $\mathrm{Mr}$ F Gill and Mrs D Glass for advice on exposure assessment and management, and the workers for their cooperation. The work was supported by grants from the Health and Safety Executive, the National Asthma Campaign, the Department of Health and Social Security and the Royal Society.

1 Cullinan P, Lowson D, Nieuwenhuijsen MJ, Gordon S, Tee RD, Venables KM, McDonald JC, Newman Taylo AJ. Work related symptoms, sensitisation, and estimated exposure in workers not previously exposed to laboratory rats. Occup Environ Med 1994;51:589-92.

2 Meredith SK, Taylor VM, McDonald JC. Occupational respiratory disease in the United Kingdom: a report to
the British Thoracic Society and the Society of Occupational Medicine by the SWORD project group Brf Ind Med 1991;48:292-8

3 Venables KM, Tee RD, Hawkins ER, et al. Laborator animal allergy in a pharmaceutical company. Br $\mathcal{F}$ Ind animal allergy in a

4 Cockcroft A, Edwards J, McCarthy P, Andersson N Allergy in laboratory animal workers. Lancet 1981;i 827-30.

5 Slovak AJM, Hill RN. Laboratory animal allergy: a clinical survey of an exposed population. Br f Ind Med 1981;38 38-41.

6 Newman Taylor AJ, Longbottom JL, Pepvs J. Respiratory allergy to urine proteins of rats and mice. Lancet 1977;ii: $847-9$

7 Agarwal MK, Yunginger JW, Swanson MC, Reed CE. An immunochemical method to measure atmospheric allerimmunochemical method to measure atmosph

8 Gordon S, Tee RD, Lowson D, Wallace J, Newman Taylor AJ. Reduction of airborne allergenic urinary proTaylor AJ. Reduction of airborne allergenic urinary pro
teins from laboratory rats. $B r \mathcal{F}$ Ind Med 1992;49:416-9.

teins from laboratory rats. Br $\mathcal{F}$ Ind Med $1992 ; 49: 416-9$.
9 Blanchet Y. Evaluation of exposure to mouse and rat urinary proteins amongst employees of the Montreal General Hospital Research Institute. Montreal: School of Occupational Health, McGill University, 1988. (MSc Thesis.)

10 Swanson MC, Atkinson S, Nieuwenhuijsen MJ, Newman Taylor AJ. Development of personal sampling strategies for occupational exposure to airborne laboratory animal allergens. $₹$ Allergy Clin Immunol 1990;85:227.

11 Eggleston PA, Newill CA, Ansari AA, et al. Task related variation in airborne concentrations of laboratory animal allergens: studies with Rat n 1. 7 Allergy Clin Immunol 1989;84:347-52.

12 Edwards RG, Beeson MF, Dewdney JM. Laboratory animal allergy: the measurement of airborne urinary allergens and the effect of different environmental gens and the effect of differen

13 Corn M, Esmen A. Workplace exposure zone for classification of employee exposures to physical and chemica agents. Am Ind Hyg Assoc f 1979;40:47-57.

14 Gordon S, Tee RD, Lowson D, Newman Taylor AJ Comparison and optimization of filter elution method for the measurements of airborne allergen. Ann Occup Hyg 1992;36:575-87.

15 Gordon S, Tee RD, Nieuwenhuijsen MJ, Lowson D, Harris J, Newman Taylor AJ. Measurement of airborne rat urinary allergen in a longitudinal epidemiological study. Clin Exp Allergy (in press) 